\title{
Effect of Seed Rate and Dibbling on Growth, Yield Attributes and Yield of Different Varieties of Wheat (Triticum aestivum) in Madhya Pradesh, India
}

\author{
A. K. Jha*, Suneeta Pandey and R. S. Shukla \\ AICRP on Wheat, Department of Plant Breeding \& genetics, Jawaharlal Nehru Krishi \\ Vishwavidyalaya, Jabalpur, Madhya Pradesh 482 004, India \\ *Corresponding author
}

\begin{tabular}{l} 
Key w o r d s \\
$\begin{array}{l}\text { Seed rate, Spacing, } \\
\text { Wheat and } \\
\text { economics }\end{array}$ \\
\hline Article Info \\
\hline $\begin{array}{l}\text { Accepted: } \\
15 \text { May } 2020 \\
\text { Available Online: } \\
\text { 10 June } 2020\end{array}$ \\
\hline
\end{tabular}

A B S T R A C T

Field experiment was conducted at Research Farm AICRP on Wheat Department of Plant Breeding and Genetics, Jawaharlal Nehru Krishi Vishwa Vidyalaya, Jabalpur (M.P.) during Rabi season, 2016-17. The experiment consisted of 12 treatment combinations viz. in main plot 2 seed rates $(50$ and $100 \mathrm{~kg} / \mathrm{ha}$ at $20 \mathrm{~cm})$ and 3 spacing $(15 \times 15,20 \times 15$ and $20 \times 20$ $\mathrm{cm}$ dibbling) and whereas sub plot included genotypes (HI 1544, HI 8737). The highest yield was obtained in dibbling $15 \times 15 \mathrm{~cm}(50.13 \mathrm{q} / \mathrm{ha})$ followed by line sowing @ $20 \mathrm{~cm}$ with seed rate of $100 \mathrm{~kg} / \mathrm{ha}(49.54 \mathrm{q} / \mathrm{ha})$ but the differences were not significant. The increment in yield may be attributed to higher number of earheads/sq. m. The other planting options recorded significantly lower yield as compared to these two methods. The cultivar HI 8737 yielded significantly higher (47.91q/ha) as compared to HI 1544 (46.43 q/ha).

\section{Introduction}

Wheat is the largest cultivated crop with an estimated area of 220.19 million hectares (mha), and barley is grown in $50.55 \mathrm{mha}$. The nutritious cereals altogether have been under cultivation in 270.74 mha with an estimated production of 932.89 million tonnes $(\mathrm{mt})$ for the period 2018-19 (UDSA, 2019). In India, during 2018-19 Rabi season, wheat was cultivated in $29.55 \mathrm{mha}$ and barley in 0.66 mha, constituting 24.35 per cent of the total crop acreage. India harvested an all time record wheat production of more than 97 million tonnes during the year 2016-17 despite shrinking land and water resources, climate abrasions and little genetic gain. This has been made possible by Indian farmers and scientists through efficient management of natural resources and various external inputs like chemical fertilizers and pesticides. Wheat is generally planted by broadcast method by most of the farmers in the country and only progressive farmers and researchers use line 
sowing. Now-a-days due to infestation of weeds, it has become necessary to sow the crop in lines with a suitable row spacing, which may help in cultural operations, herbicides application, inter-cropping and increasing or decreasing seed rate without any adverse effect on the final grain yield. Proper row spacing is important for maximizing light interception, penetration, distribution in crop canopy and average light utilization efficiency of the leaves in the canopy, and thus affect yield of a crop. Wider spacing between rows or pairs of rows, not only allow more light to reach the lower leaves at the time of grain formation but also allows easy inter-culture for weed control and inter-cropping (Biswas et al., 1999). The wheat productivity greatly depends on availability of nutrients and moisture, besides the climatic factors. Farmers in Kymore plateau often face problem in rabi crop sowing due to delayed harvesting of kharif crop. Plant population also affects wheat yield considerably. There fore, the optimum seeding rate is crucial for getting high yield of wheat in various regions (Lloveras, et al., 2004). Sowing depth significantly influences the emergence and vigor of seedlings contributing greatly to crop stand and yield (Roy et al., 2011). In the future scenario of climate change better agronomical practices would help in adaptation and resilience of crops. The present study was undertaken to identify optimum seeding rate and sowing depth of wheat for better yields in Kymore plateau region of Madhya Pradesh.

\section{Materials and Methods}

Field experiment was conducted at Research Farm AICRP on Wheat Department of Plant Breeding and Genetics, Jawaharlal Nehru Krishi Vishwa Vidyalaya, Jabalpur (M.P.) during Rabi season, 2016-17. The topography of the field in experimental area was fairly uniform. All facilities including irrigation water were adequately available on the research farm to carry out the field experiment. texture with $236.8 \mathrm{~kg} / \mathrm{ha}$ available N (Subbaih and Asija, 1956), 20.10 $\mathrm{kg} / \mathrm{ha}$ available $\mathrm{P}$ (Olsen et al., 1954), $272.3 \mathrm{~kg} / \mathrm{ha}$ available K (Jackson, 1967) $0.62 \%$ organic carbon and soil $\mathrm{pH}$ of 7.3 (1:2.5 soil and water ratio). This trial was conducted in split plot design to evaluate the effect of planting options and spacing on wheat productivity. The experiment consisted of 12 treatment combinations viz. in main plot 2 seed rates (50 and $100 \mathrm{~kg} / \mathrm{ha}$ at $20 \mathrm{~cm}$ ) and 3 spacing $(15 \times 15,20 \times 15$ and $20 \times 20 \mathrm{~cm}$ dibbling) and whereas sub plot included genotypes (HI 1544, HI 8737). NPK was applied in the ratio of 120:60:40 (1/3rd N, full $\mathrm{P} \& \mathrm{~K}$ as basal and the remaining $2 / 3 \mathrm{rd}$ nitrogen as $1 / 3 \mathrm{rd}$ at first irrigation and next $1 / 3$ rd at second irrigation. Crop was grown under optimal crop management practices with $120 \mathrm{~kg} \mathrm{~N}, 60 \mathrm{~kg} \mathrm{P} 2 \mathrm{O} 5$ and $40 \mathrm{~kg}$ $\mathrm{K} 2 \mathrm{O} / \mathrm{ha}$. Irrigation was provided as per the need of crop. Crop was kept weed free by regular hand weeding. The data on growth parameters, yield attributes and yields were recorded as per the standard procedures.

\section{Results and Discussion}

\section{Plant population}

The initial plant population significantly higher $\left(132.11 \mathrm{~m}^{-2}\right)$ was recorded under the dibbling of $(20 \mathrm{x} \quad 15 \mathrm{~cm}$ dibbling). The significantly differences were not observed among the dibbling of $15 \times 15,20 \times 15 \mathrm{~cm}$. The plant population at harvest were recorded $\left(167.8 \mathrm{~m}^{-2}\right)$ higher in seed rate $50 \mathrm{~kg}$ at $20 \mathrm{~cm}$ apart (Table 1). The minimum plant population were observed under the sowing of 8737) as compare to HI 1544. The same results were reported by Yadav et al., (2001).

\section{Yield attributes}

Growth of wheat was affected by different seeding rates. Leaf area index and number of 
tillers $/ \mathrm{m}^{2}$ were maximum with seed rate of 50 $\mathrm{kg} / \mathrm{ha}$, which was on par with $100 \mathrm{~kg} / \mathrm{ha}, \mathrm{b}$ (Table 1). Similar findings were also reported by Sen et al., (2003). Effective tillers were more with $50 \mathrm{~kg} \mathrm{seed} / \mathrm{ha}$. and dibbling at $20 \mathrm{x}$ $15 \mathrm{~cm}$ with variety HI 1544 . Yield attributes such as grains/spike, grains weight/spike and 1,000 grains weight were on par with 20x 15 $\mathrm{cm}$ with variety HI 1544 under the seed rate $50 \mathrm{~kg} / \mathrm{ha}$. These results supported the findings of Kumar et al., (2002) and Singh et al., (2005).

Table.1 Effect of different treatments on growth and yield attributes characters in wheat

\begin{tabular}{|l|c|c|c|c|c|c|}
\hline Treatments & $\begin{array}{c}\text { Plant } \\
\text { population }\end{array}$ & $\begin{array}{c}\text { Plant } \\
\text { Height }\end{array}$ & $\begin{array}{c}\text { Leaf area } \\
\text { index } \\
\text { at 30 }\end{array}$ & $\begin{array}{c}\text { Leaf area } \\
\text { index } \\
\text { at 60 }\end{array}$ & $\begin{array}{c}\text { Earhead/ } \\
\text { sq.m. }\end{array}$ & $\begin{array}{c}\text { Grains/ } \\
\text { Earhead }\end{array}$ \\
\hline Seed rate & 167.8 & 73.89 & & & & \\
\hline 50kg & & & 2.69 & 4.57 & & 23.8 \\
\hline 100 kg & 149.8 & 72.87 & 2.72 & 4.60 & 349.8 & 23.8 \\
\hline CD at 5\% & 1.23 & 0.21 & 0.07 & 0,87 & & \\
\hline Spacing & & & & & \\
\hline Spacing (15X15 cm) & 213.8 & 72.55 & 2.89 & 4.84 & 533.8 & 17.8 \\
\hline Spacing (15X20 cm) & 224.8 & 74.67 & 2.76 & 4.64 & 494.8 & 19.8 \\
\hline Spacing (20X20 cm) & 214.8 & 71.23 & 2.62 & 4.65 & 441.8 & 22.8 \\
\hline CD at 5\% & 1.11 & 0.23 & 0.56 & 0.87 & & \\
\hline Varieties & & & & & & \\
\hline HI 1544 & 194.8 & 73.45 & 2.77 & 4.67 & 413.8 & 23.8 \\
\hline HI 8737 & 217.8 & 75.67 & 2.65 & 4.33 & 264.8 & 27.8 \\
\hline CD at 5\% & 1.34 & 0.45 & 0.04 & 0.55 & 1.89 & 0.44 \\
\hline
\end{tabular}

Table.2 Effect of different treatment on economics

\begin{tabular}{|c|c|c|c|c|}
\hline Treatments & $\begin{array}{c}\text { Cost of } \\
\text { Cultivation } \\
\text { Rs/ha }\end{array}$ & $\begin{array}{l}\text { GMRs } \\
\text { Rs/ha }\end{array}$ & $\begin{array}{l}\text { NMRs } \\
\text { Rs /ha }\end{array}$ & B:C ratio \\
\hline \multicolumn{5}{|l|}{ Seed rate } \\
\hline $50 \mathrm{~kg}$ & 25500 & 67999 & 42499 & 2.67 \\
\hline $100 \mathrm{~kg}$ & 26785 & 62876 & 36091 & 2.35 \\
\hline CD at $5 \%$ & 2349 & 2876 & 1234 & 0.08 \\
\hline \multicolumn{5}{|l|}{ Spacing } \\
\hline Spacing $(15 X 15 \mathrm{~cm})$ & 26667 & 65876 & 39209 & 2.47 \\
\hline Spacing $(15 X 20 \mathrm{~cm})$ & 26567 & 67555 & 40988 & 2.54 \\
\hline Spacing $(20 \times 20 \mathrm{~cm})$ & 26333 & 72654 & 46321 & 2.76 \\
\hline CD at $5 \%$ & 1769 & 2346 & 1568 & \\
\hline \multicolumn{5}{|l|}{ Varieties } \\
\hline HI 1544 & 26452 & 68975 & 42523 & 2.61 \\
\hline HI 8737 & 26432 & 73456 & 47024 & 2.78 \\
\hline CD at $5 \%$ & 1654 & 2543 & 1678 & 0.06 \\
\hline
\end{tabular}


Table.3 Effect of different treatments on yield in wheat

\begin{tabular}{|c|c|c|c|c|c|c|}
\hline $\begin{array}{l}\text { Seeding Method \& } \\
\text { Spacing }\end{array}$ & Variety & $\begin{array}{l}\text { Earhead/ } \\
\text { sq.m. }\end{array}$ & $\begin{array}{l}\text { Grains/ } \\
\text { Earhead }\end{array}$ & $\begin{array}{l}1000 \text { Grains } \\
\text { Weight, } g\end{array}$ & $\begin{array}{l}\text { Yield, } \\
\text { q/ha }\end{array}$ & $\begin{array}{c}\text { Biomass, } \\
\text { q/ha }\end{array}$ \\
\hline \multirow[t]{2}{*}{$50 \mathrm{~kg}$ seed } & HI 1544 & 379.8 & 23.8 & 49.8 & 42.11 & 69.32 \\
\hline & HI 8737 & 349.8 & 23.8 & 52.3 & 40.41 & 73.74 \\
\hline \multirow[t]{2}{*}{$100 \mathrm{~kg}$ seed } & HI 1544 & 361.8 & 25.8 & 46 & 40.41 & 80.2 \\
\hline & HI 8737 & 296.8 & 24.8 & 51.8 & 36.15 & 74.59 \\
\hline \multirow{2}{*}{$\begin{array}{l}\text { Spacing (15X15 } \\
\text { cm) }\end{array}$} & HI 1544 & 633.8 & 17.8 & 47.8 & 49.59 & 75.78 \\
\hline & HI 8737 & 494.8 & 19.8 & 54.3 & 49.08 & 78.67 \\
\hline \multirow{2}{*}{$\begin{array}{l}\text { Spacing }(15 X 20 \\
\text { cm) }\end{array}$} & HI 1544 & 441.8 & 22.8 & 48.1 & 45.17 & 79.52 \\
\hline & HI 8737 & 430.8 & 20.8 & 52.5 & 42.62 & 65.75 \\
\hline \multirow{2}{*}{$\begin{array}{l}\text { Spacing }(20 \times 20 \\
\text { cm) }\end{array}$} & HI 1544 & 413.8 & 23.8 & 49.8 & 45.17 & 72.38 \\
\hline & HI 8737 & 264.8 & 27.8 & 56.1 & 39.04 & 68.98 \\
\hline \multicolumn{2}{|c|}{ SEm \pm} & 1.79 & 3.59 & 2.548 & 3.23 & 2.78 \\
\hline \multicolumn{2}{|c|}{ CD $(5 \%)$} & 3.79 & 5.59 & 3.385 & 4.82 & 3.88 \\
\hline
\end{tabular}

Yield

There was significant different in grain yield between two variety. The wheat variety HI 1544(average 42.69 q/ha) produced significant higher grain yield than HI8737 (average $39.66 \mathrm{q} / \mathrm{ha}$.). Among planting method dibbling at $(15 \times 15 \mathrm{~cm}$.) Produced the highest and significant higher grain yield than all the other treatment. The next best planting method was sowing at $15 \times 20 \mathrm{~cm}$. The highest yield was obtained in dibbling $15 \times 15 \mathrm{~cm}$ (50.13 q/ha) followed by line sowing @ 20 $\mathrm{cm}$ with seed rate of $100 \mathrm{~kg} / \mathrm{ha}(49.54 \mathrm{q} / \mathrm{ha})$ but the differences were not significant. The increment in yield may be attributed to higher number of earheads/sq. m. The other planting options recorded significantly lower yield as compared to these two methods. The cultivar HI 8737 yielded significantly higher (47.91q/ha) as compared to HI 1544 (46.43 q/ha). Sharma and Malik, 1993 and Biswas et al., 1999 also found the similar findings.

\section{References}

Lloveras, J., Manet, J., Viudas, J., Lopez, A. and Santiveri, P. 2004. Seeding rate influenced yield and yield components of irrigated winter wheat in a Mediterranean climate. Agronomy Journal 96: 1258-65.

Roy, J., Biswas, P.K., Ali, M.H. and Rahman. A. 2011. Effect of sowing depth and population density on yield attributes and yield of wheat. Technical Journal of Engineering and Applied Sciences 1(4): 125-33.

Yadav, D.P., Vaishya, R.D. and Gajendra, Singh. 2001. Response of late sown wheat to, of sowing rates and weed management practices. Annals of Agri. Res., 22(3): 429-431

Kumar, R., Agarwal, S.K., and Nanwal, R.K. 2002. Economics of bread wheat as affected by planting system, seed rate and nitrogen fertilization in sandy loam soils of Haryana. CCSHAU Journal of 
Research 32(1): 23-25.

Singh, S., Uppal, H.S., Mahal, S.S. and Singh, A. 2006. Water use, water use efficiency and yield of bed planted wheat (Triticum aestivum L.) in relation to various seed rate, spacing and irrigation levels. Environment and Ecology 24(2): 476-79.

Sharma, R.P. and Malik, C.V.S. 1993. Effect of seed rate, nitrogen and sowing method on yield of late-sown wheat (Triticum aestivum L.). Indian Journal of Agronomy 38(2): 289-91.

Biswas, P., Kamal, A.M.A. Rahman, M.M. and Samanta, S.C. 1999. Effect of seed rate, split application of nitrogen and time of irrigation on growth, yield and protein content of wheat. Bangladesh Journal of Scientific and Industrial Research 34(2): 312-14.

Subbiah, B.V. and Asija, C.L. 1956. A rapid procedure for the estimation of available nitrogen in soil. Current Science 25(4): 259-60.

\section{How to cite this article:}

Jha, A. K., Suneeta Pandey and Shukla, R. S. 2020. Effect of Seed Rate and Dibbling on Growth, Yield Attributes and Yield of Different Varieties of Wheat (Triticum aestivum) in Madhya Pradesh, India. Int.J.Curr.Microbiol.App.Sci. 9(06): 707-711.

doi: https://doi.org/10.20546/ijcmas.2020.906.090 